\title{
PHYLOGENETIC RELATIONSHIPS OF THE EMMERICIIDAE (CAENOGASTROPODA: RISSOOIDEA)
}

\author{
MAGDALENA SZAROWSKA ${ }^{1}$, ANDRZEJ FALNIOWSKI ${ }^{2}$ \\ Department of Malacology, Institute of Zoology, Jagiellonian University, Gronostajowa 9, 30-387 Cracow, \\ Poland (e-mail: ${ }^{1}$ magdalena.szarowska@uj.edu.pl; ${ }^{2}$ andrzej.falniowski@uj.edu.pl)
}

ABSTRACT: The phylogenetic relationships of the monogeneric rissooid family Emmericiidae Brusina, 1870 are unclear. The single genus Emmericia Brusina, 1870 occurs along the Adriatic coast from NE Italy to southern Croatia. It is characterised by the peculiar anatomy of the male genitalia (tri-lobed penis, bifurcate flagellum and penial gland). Mitochondrial cytochrome oxidase subunit I (COI) gene sequences, analysed together with nuclear 18S ribosomal RNA gene sequences, showed Bithyniidae and Bythinellidae as the sister taxa of the Emmericiidae, and confirmed the homology of the flagellum and penial gland in the Emmericiidae, Bythinellidae, Amnicolidae and Bithyniidae.

KEY WORDS: molecular phylogeny, cytochrome oxidase, 18S rRNA, Bayesian analysis, flagellum, penial gland, homology

\section{INTRODUCTION}

Emmericia Brusina, 1870, the type species E. patula (Brumati, 1838), is found along the Adriatic coast from North-East Italy to the south of Croatia. Apart from this range, isolated localities are known from France and Germany, but the latter are due to introductions (BRUSINA 1870, BOURGUIGNAT 1880, BOETERS \& Heuss 1985, MOUTHON 1986, KABAT \& HERSHLER 1993, GLÖER 2002, GARGOMINY et al. 2011). The representatives of the genus inhabit rivers and springs (GIUSTI \& PEZZOLI 1980, RADOMAN 1983, BOETERS 1998, GLÖER 2002). Emmericia patula (Brumati, 1838) is known from Monfalcone in Italy to the Neretva River in Croatia, not exceeding an altitude of about $70 \mathrm{~m}$ a.s.l. RADOMAN (1967, 1968, 1970, 1983) lists three more species inhabiting Croatia, Serbia and Bosnia. One of them occurs in the Neretva River, the other two are found locally in springs.

The genus is characterised by a unique, tri-lobed penis with a bifurcating flagellum and a penial gland, and a radula with no basal cusps on the rhachidian teeth. The phylogenetic relationships of Emmericia are enigmatic. BRUSINA (1870) established a monogeneric subfamily Emmericiinae, within the Rissoidae, and further discussed its position (BRUSINA 1874a, b).
BOURGUignAT $(1877,1880)$ placed the genus Emmericia in the Melaniidae (Cerithioidea). THIELE (1929-1935) placed Emmericieae, with Emmericia as the only genus, in the Hydrobiidae, subfamily Hydrobiinae, not far from the Lithoglypheae, Benedictieae, and Amnicoleae. RADOMAN (1967, 1968, 1970) reviewed the genus Emmericia, considering it anatomically most similar to Lithoglyphus Hartmann, 1821. GiUsti \& PEZZOLI (1980) and MOUTHON (1986) redescribed the genus, placing it in the family Emmericiidae, superfamily Pyrguloidea. PONDER \& WARÉN (1988) included the subfamily Emmericiinae in the Hydrobiidae, placing the former close to the Baicaliinae, Benedictiinae and Tateinae, and far from the Lithoglyphinae and Amnicolinae. SZAROWSKA (2006a) inferred a phylogeny of Emmericia. Unfortunately, since several efforts of amplifying mitochondrial cytochrome oxidase subunit I (COI) gene had given no results (SZAROWSKA 2006a, WILKE personal communication), the phylogeny was based on the nuclear 18S rRNA gene sequence alone. Despite those limitations, it showed Emmericia as belonging neither to the Hydrobiidae nor to the Pomatiopsidae, Cochliopidae, and Tateidae, but clustering 
in a big group together with Bythinella, Lithoglyphidae, Amnicolidae, and Bithyniidae. It was impossible to assess which of these taxa was the closest relative of Emmericia. In an appendix of SZAROWSKA (2006b) the literature data on the morphology of Emmericia were summarised, and SEM photographs of the shell surface and radula, morphology of the penis and female reproductive organs, and histology of the penis and flagellum (penial gland) were presented. The maximum-parsimony phylogenetic analysis of all those morphological characters showed Bithynia Leach, 1818 as the sister taxon of Emmericia, and Bythinella Moquin-Tandon, 1855 and Amnicola Gould et Haldeman, 1840 as its close relatives.

The aim of the present paper is to establish phylogenetic relationships of Emmericia (to find its sisterclade) and to test homology of the flagellum and penial gland, applying cytochrome oxidase subunit I sequences, recently obtained in our laboratory.

\section{MATERIAL AND METHODS}

Material was collected from the Zrmanja River at Berberi, Croatia, 44 $11^{\prime} 48.6^{\prime \prime} \mathrm{N}, 15^{\circ} 46^{\prime} 04.6^{\prime \prime} \mathrm{E}, 11 \mathrm{~m}$ a. s. 1., in June 2011, with the use of a sieve of $0.5 \mathrm{~mm}$ mesh size. Snails were washed twice in $80 \%$ ethanol and left to stand in it for around 12 hours. Then the ethanol was changed twice more within 24 hours and finally, after a few days, the $80 \%$ solution was replaced with a $96 \%$ one, in which the samples were stored at $-20^{\circ} \mathrm{C}$.

DNA was extracted from foot tissue of two snails. The tissue was hydrated in TE buffer $(3 \times 10 \mathrm{~min}$. $)$; then total genomic DNA was extracted with the SHERLOCK extracting kit (A\&A Biotechnology), and the final product was dissolved in $20 \mu \mathrm{l}$ TE buffer. The PCR reaction was performed with the following primers: LCO1490 (5'-GGTCAACAAATCATAAAGATAT TGG-3') (FOLMER et al. 1994) and COR722b

Table 1. Taxa used for phylogenetic analyses, with their GenBank Accession Numbers and references

\begin{tabular}{|c|c|c|c|}
\hline Species & 18S GB\# & COI GB\# & References \\
\hline Adriohydrobia gagatinella (Küster, 1852) & AF367657 & AF317881 & WILKE \& FALNIOWSKI (2001) \\
\hline Adrioinsulana conovula (Frauenfeld, 1863) & AF367656 & AF367628 & WILKE et al. (2001) \\
\hline Alzoniella finalina Giusti et Bodon, 1984 & AF367686 & AF367650 & WILKE et al. (2001) \\
\hline Amnicola limosa (Say, 1817) & AF212916 & AF213348 & WILKE et al. (2000b) \\
\hline Bithynia tentaculata (Linnaeus, 1758) & AF367675 & AF367643 & WILKE et al. (2001) \\
\hline Bythinella austriaca (Frauenfeld, 1857) & AF212917 & FJ545132 & FALNIOWSKI et al. (2009) \\
\hline Bythiospeum sp. & AF367664 & AF367634 & WILKE et al. (2001) \\
\hline Dianella thiesseana (Kobelt, 1878) & AY676125 & AY676127 & SZAROWSKA et al. (2005) \\
\hline Emmericia patula (Brumati, 1838) 6E66 & KC810057 & KC810059 & present study \\
\hline Emmericia patula (Brumati, 1838) 6E52 & KC810058 & KC810060 & present study \\
\hline Graziana alpestris (Frauenfeld, 1863) & AF367673 & AF367641 & WILKE et al. (2001) \\
\hline Heleobia dalmatica (Radoman, 1974) 1 & AF367661 & AF367631 & WILKE et al. (2001) \\
\hline Horatia klecakiana Bourguignat, 1887 & AF367669 & AF367637 & WILKE et al. (2001) \\
\hline Hydrobia acuta (Draparnaud, 1805) & AF367680 & AF278808 & WILKE \& Davis (2000) \\
\hline Islamia piristoma Bodon et Cianfanelli, 2001 & AF367671 & AF367639 & WILKE et al. (2001) \\
\hline Lithoglyphus naticoides (C. Pfeiffer, 1828) & AF367674 & AF367642 & WILKE et al. (2001) \\
\hline Marstoniopsis insubrica (Küster, 1853) & AF367676 & AY027813 & FALNIOWSKI \& WILKE (2001) \\
\hline Pomatiopsis lapidaria (Say, 1817) & AF367666 & AF367636 & WILKE et al. (2001) \\
\hline Pyrgula annulata (Linnaeus, 1767) & AY676124 & AY341258 & SZAROWSKA et al. (2005) \\
\hline Radomaniola callosa (Paulucci, 1881) & AF367685 & AF367649 & WILKE et al. (2001) \\
\hline Rissoa labiosa (Montagu, 1803) & AY676126 & AY676128 & SZAROWSKA et al. (2005) \\
\hline Sadleriana fluminensis (Küster, 1853) & AF367683 & AY273996 & WILKE et al. (2001) \\
\hline Tricula wumingensis $\mathrm{Hu}$ et al., 1994 & (P. lapidaria) & EF394892 & GUAN et al. (2008) \\
\hline Tricula pingi Kang, 1984 & (P. lapidaria) & EF394901 & GUAN et al. (2008) \\
\hline Ventrosia ventrosa (Montagu, 1803) & AF367681 & AF118335 & WILKE \& DAVIS (2000) \\
\hline
\end{tabular}


(5' -TAAACTTCAGGGTGACCAAAAAATYA-3') (WILKE \& DAVIS 2000) for the mitochondrial cytochrome oxidase subunit I (COI) gene, and SWAM18SF1 (5'-GAATGGCTCATTAAATCAGT CGAGGTTCCTTAGATGATCCAAATC-3'), and SWAM18SR1 (5'-ATCCTCGTTAAAGGGTTTAAAGT GTACTCATTCCAATTACGGAGC-3') for the nuclear 18S rRNA gene (PALUMBI 1996). The PCRs were run on Biometra TProfessional thermocycler. The PCR conditions were as follows: COI - initial denaturation step of $4 \mathrm{~min}$ at $94^{\circ} \mathrm{C}$, followed by 35 cycles of 1 min at $94^{\circ} \mathrm{C}, 1 \mathrm{~min}$ at $48^{\circ} \mathrm{C}, 2 \mathrm{~min}$ at $72^{\circ} \mathrm{C}$, and a final extension of 4 min at $72^{\circ} \mathrm{C} ; 18 \mathrm{~S}$ - initial denaturation step of $4 \mathrm{~min}$ at $94^{\circ} \mathrm{C}$, followed by 40 cycles of $45 \mathrm{~s}$ at $94^{\circ} \mathrm{C}$, $45 \mathrm{~s}$ at $51^{\circ} \mathrm{C}, 2 \mathrm{~min}$ at $72^{\circ} \mathrm{C}$ and, after all cycles were completed, an additional elongation step of $4 \mathrm{~min}$ at $72^{\circ} \mathrm{C}$ was performed. The total volume of each PCR reaction mixture was $50 \mu \mathrm{l}$. To check the quality of the PCR products $10 \mu \mathrm{l}$ of the PCR product was ran on $1 \%$ agarose gel. The PCR products were purified using Clean-Up columns (A\&A Biotechnology) and the purified PCR products were amplified in both directions (HILlis et al. 1996) using BigDye Terminator v3.1 (Applied Biosystems), following the manufacturer's protocol and with the primers described above. The sequencing reaction products were purified using ExTerminator Columns (A\&A Biotechnology); DNA sequences then underwent electrophoresis on an ABI Prism sequencer. All the sequences were deposited in GenBank (Table 1).

Four COI sequences were aligned by eye using BioEdit 5.0.0 (HALL 1999). For 18S, an initial alignment was performed using CLUSTALX 1.82 (THOMPSON et al. 1997) and edited with MACCLADE4.05 (MADDISON \& MADDISON 2002). Mutational saturation for the COI dataset was examined by plotting the numbers of transitions and transversions for all the codon positions together, and for the 3rd position separately, against the percentage sequence divergence, using DAMBE 5.2.9 (XIA 2000). We also used DAMBE 5.2.9 to perform the saturation test (XIA et al. 2003). It revealed a significant degree of saturation in the third position of the sequences. In rissooids, COI approaches saturation with about $18.6 \%$ or 120 nucleotide differences (DAVIS et al. 1998, WILKE et al. 2000a), which seems to happen after approximately 10 million years. However, to avoid a substantial loss of information in the case of closely related species, this position was not excluded from the dataset and it was used for the analysis.

The partition homogeneity test (FARRIS et al. $1995)$ was performed (1,000 replicates) with PAUP**4.0b10 (SWOFFORD 2002), to check whether the two genes could be analysed together. Since the results of the test were positive $(p=0.789)$, the sequences were analysed together. For each maximum likelihood (ML) analysis, we used the best fit model of sequence evolution found by Modeltest v3.06
(POSADA \& Crandall 1998, POSADA 2003). Following the recommendations of POSADA \& BUCKLEY (2004) and SOBER (2002), the best model for each dataset was chosen using the Akaike Information Criterion (AKAIKE 1974). We performed ML analyses in PAUP* and used a heuristic search strategy with stepwise addition of taxa, 10 random-sequence addition replicates, and tree-bisection-reconnection (TBR) branch swapping (SWOFFORD et al. 1996). Nodal support was estimated using the bootstrap (BS) approach (FELSENSTEIN 1985). Bootstrap values for ML trees were calculated using 1,000 bootstrap replicates, the "fast" heuristic search algorithm, and the same model parameters as for each ML analysis. Additionally, we ran ML analysis in PAUP with option "estimate" for all the model parametres.

For Bayesian inference (BA) we used MRBAYES 3.1.2 (HUELSENBECK \& RONQUIST 2001, RONQUIST \& HUELSENBECK 2003). We selected the best model of sequence evolution for each data set using MrModeltest 2.2 (NYLANDER 2004), applying the Akaike Infor-

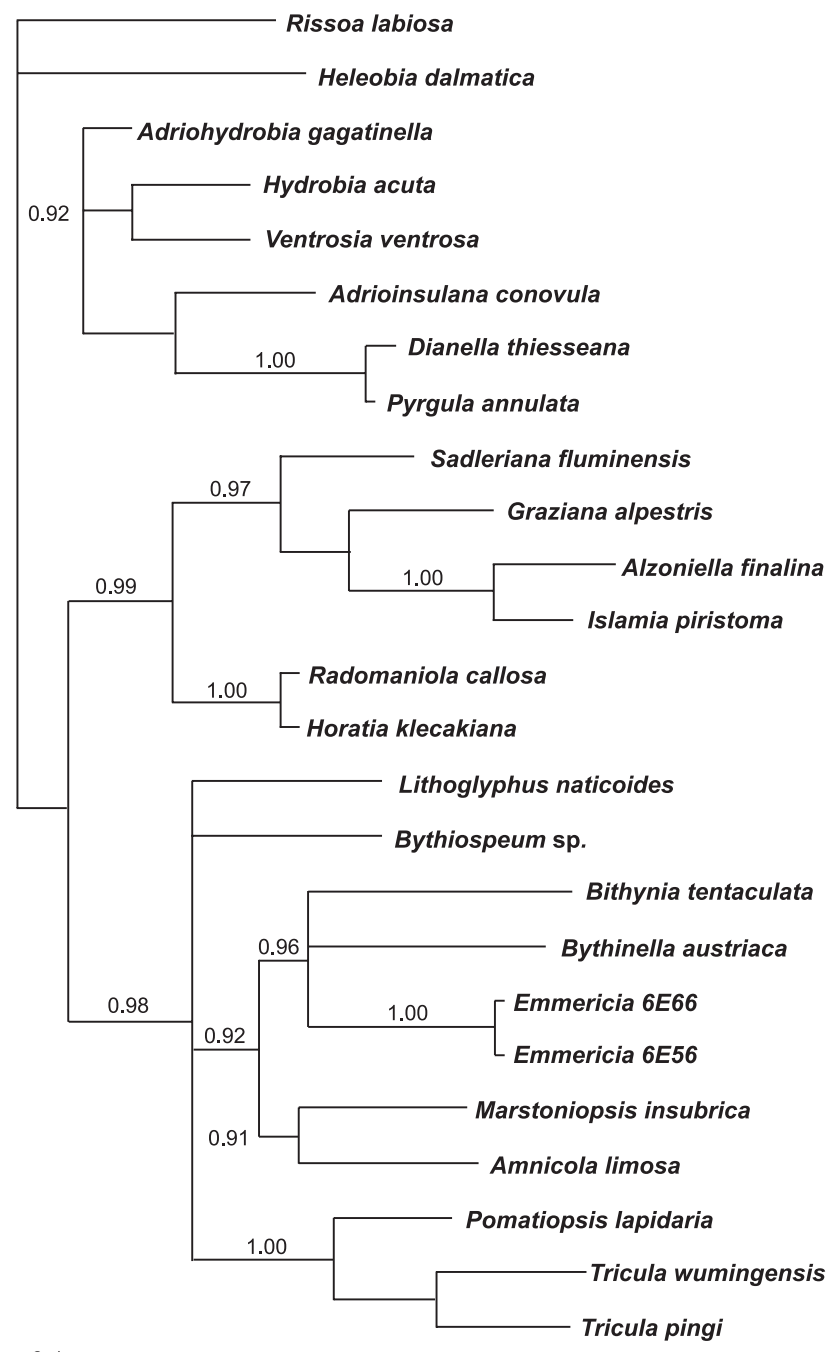

$\underline{0.1}$

Fig. 1. Bayesian phylogenetic tree. Bayesian probabilities given where $>0.90$ 
mation Criterion (POSADA \& BUCKLEY 2004). The Bayesian inference was performed with the following parameters: 4 chains in two parallel analyses $(1$ cold, three heated; $\mathrm{T}=0.15)$ Metropolis-Coupled Monte Carlo analysis run twice in parallel for 80,000,000 generations, trees sampled every 1,000 generations starting after a burn-in of 3,000,000 generations (the value chosen according to the log-likelihood values). The Bayesian inference was run unless the parallel runs

\section{RESULTS}

In both ML and BA trees Emmericia clustered outside the Hydrobiidae/Cochliopidae group, with Lithoglyphidae, Bythiospeum, Bithyniidae, Bythinellidae, Amnicolidae and Pomatiopsidae. ML analysis run with option "estimate" for all the model parameters resulted in more reliable trees, since in the trees inferred with the model found by the Modeltest Bythinella was outside all the flagellum-bearing taxa, close to the Pomatiopsidae. However, in all the ML trees Lithoglyphus appeared as the sister taxon of

\section{DISCUSSION}

It is evident that Emmericiidae are not closely related to the "Pyrgulidae" (the latter belong to the Hydrobiidae: SZAROWSKA et al. 2005), which contradicts GiUsTi \& PEZzOLI (1980). Interestingly, the ML trees seemed to confirm the close relationships between Emmericia and Lithoglyphus as postulated by RADOMAN (1968) and (in part) by the 18S phylogeny in SZAROWSKA (2006a). However, all the ML-inferred relationships were weakly supported (bootstrap values less than $50 \%$ ). As a general rule bootstrap supports are lower than the corresponding Bayesian probabilities (SUZUKI et al. 2002, DOUADY et al. 2003, ERIXON et al. 2003, WILCOX et al. 2003).

BA resulted in a grouping supported by significant Bayesian probabilities. The Bayesian probability 0.96 was found for the clade consisting of Emmericia, Bithynia and Bythinella, thus the latter two genera are putative (an unresolved, most probably soft trichotomy) sister taxa of Emmericia, which agrees with the morphology-based phylogeny presented by SzAROWSKA

\section{REFERENCES}

AKAIKE H. 1974. A new look at the statistical model identification. IEEE Trans. Automat. Contr. 19: 716-723. doi: 10.1109/TAC.1974.1100705

Boeters H. D. 1998. Mollusca: Gastropoda: Superfamilie Rissooidea. In: Brauer A., SCHWOERBEL J., ZWICK P. achieved convergence (split frequency standard deviations $<0.001)$. The partition was set, with COI treated as coding and $18 \mathrm{~S}$ as noncoding. We inferred final consensus trees with Bayesian probabilities.

In the phylogeny reconstruction, we used 23 rissooid taxa sequences from GenBank (Table 1), selected to represent all the main lineages of the freshwater Rissooidea, with a better representation of the flagellum-bearing taxa.

Emmericia. As the bootstrap support for this grouping was less than $50 \%$, we do not present those trees.

In the Bayesian tree (Fig. 1), the significantly supported (Bayesian probability 0.98) clade consisted of Bithynia, Bythinella, Emmericia, Amnicolidae and Pomatiopsidae. Close to significant (0.92) was the probability of the clade consisting of Bithynia, Bythinella, Emmericia, and Amnicolidae (Fig. 1). An unresolved trichotomy, with a significant probability (0.96), was formed by Emmericia and Bithynia, and Bythinella as the sister clade of the former.

(2006b). Recently, WILKE et al. (2013) inferred similar relationships of the Emmericiidae based on $18 \mathrm{~S}$ and $16 \mathrm{~S}$ rRNA sequences. The BA phylogeny confirms the homology of the flagellum and penial gland within the Rissooidea. It must be pointed out, however, that a flagellum and penial gland may be secondarily lost, as it is in the case of Pseudobithynia Glöer et Pešić, 2006 (SZAROWSKA 2006a). Recently a flagellum with a small but typical penial gland was found in the newly described hydrobiid genus Agrafia Szarowska et Falniowski, 2011 (SZAROWSKA \& FALNIOWSKI 2011). So far, the homology of those structures in Agrafia remains enigmatic.

\section{ACKNOWLEDGEMENTS}

The study was supported by a grant from the National Science Centre $(2011 / 01 / \mathrm{B} / \mathrm{NZ8} / 01721)$ to ANDRZEJ FALNIOWSKI.

(eds). Süsswasserfauna von Mitteleuropa. 5/1-2. Gustav Fischer Verlag, Jena - Lübeck - Ulm.

BOeters H. D., Heuss K. 1985. Emmericia patula (Brumati) rezent in Süddeutschland (Prosobranchia: Emmericiidae). Heldia 1: 105-106. 
BourguignAt J.-R. 1877. Descriptions de deux nouveaux genres Algériens, suivies d'une classification des familles et des genres de mollusques terrestres et fluviatiles du système européen. Bull. Soc. Sci. Phys. Nat. Toulouse 3: 49-101. doi: 10.5962/bhl.title.10451

BourguignAT J.-R. 1880. Monographie du genre Emmericia. Imprimerie P. Lachèse et Dolbeau, Angers.

BRUSINA S. 1870. Monographie der Gattungen Emmericia und Fossarulus. Verh. der Kaiserl.-König. Zool.-Bot. Gesell. Wien 20: 925-938.

BRUSINA S. 1874a. Prilozi paleontologij hrvatskoj ili kopnene i slatkovodne terciarne izkopine Dalmacije, Hrvatske i Slavonije. Rad Jugosl. Akad. Znan. Umjet. Zagreb 28: $1-109$.

BRUsina S. 1874b. Fossile Binnen-Mollusken aus Dalmatien, Kroatien und Slavonien nebst einem Anhange. Druck der Actienbuchdruckerei, Agram (German translation of BRUSINA 1874a, with supplement).

Davis G. M., Wilke T., SpOlsky C., QIU C.-P., QIU D.-C., XIA M.-Y., Zhang Y., RosenberG G. 1998. Cytochrome oxidase I-based phylogenetic relationships among the Pomatiopsidae, Hydrobiidae, Rissoidae and Truncatellidae (Gastropoda: Caenogastropoda: Rissoacea). Malacologia 40: 251-266.

Douady C. J., Delsuc F., Boucher Y., Doolittle W. F., DOUZERY E. J. P. 2003. Comparison of Bayesian and maximum likelihood bootstrap measures of phylogenetic reliability. Mol. Biol. Evol. 20: 248-254. doi: 10.1093/ molbev/msg042

Erixon P., Svennblad B., Britton T., Oxelman B. 2003. Reliability of Bayesian posterior probabilities and bootstrap frequencies in phylogenetics. Syst. Biol. 52: 665-673. doi: 10.1080/10635150390235485

FAlNiOWSKI A., Szarowska M., SIRBU I. 2009. Bythinella Moquin-Tandon, 1856 (Gastropoda: Rissooidea: Bythinellidae) in Romania: species richness in a glacial refugium. J. Nat. Hist. 43: 2955-2973. doi: 10.1080/ 00222930903359636

FALNIOWSKI A., WiLKE T. 2001. The genus Marstoniopsis (Gastropoda: Rissooidea): intra- and intergeneric phylogenetic relationships. J. Moll. Stud. 67: 483-488. doi: 10.1093/mollus/67.4.483

FArris J. S., Källersjö M., Kluge A. G., Bult C. 1995. Testing significance of incongruence. Cladistics 10: 315-319. doi: 10.1111/j.1096-0031.1994.tb00181.x

FELSENSTEIN J. 1985. Confidence limits on phylogenies: an approach using the bootstrap. Evolution 39: 783-791. doi: $10.2307 / 2408678$

FOlmer O., Black M., HOEH W., LUtZ R. A., VRIJENHOEK R. C. 1994. DNA primers for amplification of mitochondrial cytochrome c oxidase subunit I from diverse metazoan invertebrates. Mol. Mar. Biol. Biotechnol. 3: 294-299.

Gargominy O., Prie V., Bichain J.-M., Cucherat X., FonTAIne B. 2011. Liste de référence annotée des mollusques continentaux de France. MalaCo 7: 307-382.

GiUsti F., Pezzoli E. 1980. Gasteropodi, 2 (Gastropoda: Prosobranchia; Hydrobioidea, Pyrguloidea). Collana del progetto finalizzato "Promozione della qualitŕ dell'ambiente," Consiglio Nazionale delle Ricerche, Ve- rona, $\mathrm{AQ} / 1 / 47$. Guide per il riconoscimento delle specie animali delle acque interne Italiane 8: 1-67.

GLÖER P. 2002. Mollusca I. Süsswassergastropoden Nordund Mitteleuropas. Bestimmungsschlüssel, Lebensweise, Verbreitung. 2. neubearbeitete Auflage. Die Tierwelt Deutschlands 73. ConchBooks, Hackenheim.

GuAN F., NiU A. O., ATTwOOD S. W., LI Y. L., ZHANG B., ZHU Y. H. 2008. Molecular phylogenetics of Triculine snails (Gastropoda: Pomatiopsidae) from southern China. Mol. Phyl. Evol. 48: 702-707. doi: 10.1016/ j.ympev.2008.04.021

HALL T. A. 1999. BioEdit: a user-friendly biological sequence alignment editor and analysis program for Windows 95/98/NT. Nucl. Acids Symp. Series 41: 95-98.

Hillis D. M., MABLE B. K., LARSON A., DAVIS S. K., ZiMMER E. A. 1996. Nucleic acids IV: sequencing and cloning. In: Hillis D. M., Moritz C., MABle B. K. (eds). Molecular systematics. 2 ed. Sinauer Associates Inc., Sunderland, Massachusetts, pp. 321-381.

HuELSENBECK J. P., RONQUIST F. 2001. MRBAYES: Bayesian inference of phylogeny. Bioinformatics 17: 754-755. doi: 10.1093/bioinformatics/17.8.754

KABAT A. R., HERSHLER R. 1993. The prosobranch snail family Hydrobiidae (Gastropoda: Rissooidea): review of classification and supraspecific taxa. Smithsonian Contrib. Zool. 547: 1-94. doi: 10.5479/si.00810282.547

MADDISON D. R., MADDISON W. P. 2002. MACCLADE. Ver. 4.05. [Computer software and manual]. Sinauer Associates Inc. Publishers, Sunderland, Massachusetts.

Mouthon J. 1986. Emmericia patula (Gasteropoda, Emmericiidae) et Menetus (Gasteropoda, Planorbidae), deux espèces nouvelles pour la faune de France. Basteria 50: 181-188.

NYLANDER J. A. A. 2004. MrModeltest Ver. 2. [Computer software and manual distributed by the author] Evolutionary Biology Centre, Uppsala University, Uppsala.

PALUMBI S. R. 1996. Nucleic Acids II: The polymerase chain reaction. In: Hillis D. M., MORITZ C., MABLE B. K. (eds). Molecular systematics. 2 ed. Sinauer Associates Inc., Sunderland, Massachusetts, pp. 205-247.

PONDER W. F., WARÉn A. 1988. Classification of the Caenogastropoda and Heterostropha - a list of the family-group names and higher taxa. Malacol. Rev. Suppl. 4: 288-326.

POSADA D. 2003. Selecting models of evolution. In: SALEMI M., VANDAMME A.-M. (eds). The phylogenetic handbook. A practical approach to DNA and protein phylogeny. Cambridge University Press, Cambridge, pp. 256-282.

PosADA D., BUCKLEY T. R. 2004. Model selection and model averaging in phylogenetics: advantages of Akaike Information Criterion and Bayesian approaches over Likelihood Ratio Tests. Syst. Biol. 53: 793-808. doi: 10.1080/ 10635150490522304

PosadA D., Crandall K. A. 1998. Modeltest: testing the model of DNA substitution. Bioinformatics 14: 817-818. doi: 10.1093/bioinformatics/14.9.817

RADOMAN P. 1967. Speciation of the genus Emmericia (Gastropoda). Basteria 31: 27-43. 
RADOMAN P. 1968. The zoogeographical and phylogenetic interrelations of the genera Lithoglyphus and Emmericia. Glasnik Prirodn. Mus. Beograd B 21: 43-49.

RADOMAN P. 1970. On the taxonomy and biogeography of Hydrobiidae. Malacologia 9: 173-177.

RADOMAN P. 1983. Hydrobioidea a superfamily of Prosobranchia (Gastropoda). I Systematics. Serbian Academy of Sciences and Arts, Monograph 547, Department of Sciences 57: 1-256.

RONQUist F., HUElSENBECK J. P. 2003. MRBAYES 3: Bayesian phylogenetic inference under mixed models. Bioinformatics 19: 1572-1574. doi: 10.1093/ bioinformatics/btg180

SOBER E. 2002. Instrumentalism, parsimony, and the Akaike framework. Philos. Sci. 69: 112-123. doi: 10.1086/ 341839

SUZUKI Y., GLAZKo G. V., NEI M. 2002. Overcredibility of molecular phylogenies obtained by Bayesian phylogenetics. Proc. Nat. Acad. Sci. U.S.A. 99: 16138-16143. doi: $10.1073 /$ pnas.212646199

SWOFFORD D. L. 2002. PAUP*_Phylogenetic analysis using parsimony (* and other methods). Ver. 4. [Computer software and manual]. Sinauer Associates Inc., Sunderland, Massachusetts.

SWOFFord D. L., Olsen G. J., WAdDell P. J., Hillis D. M. 1996. Phylogenetic inference. In: HILLIS D. M., MORITZ C., Mable B. K. (eds). Molecular systematics. 2 ed. Sinauer Associates Inc., Sunderland, Massachusetts, pp. 407-514.

SZAROWSKA M. 2006a. Molecular phylogeny, systematics and morphological character evolution in the Balkan Rissooidea (Caenogastropoda). Folia Malacol. 14: 99-168.

SZAROWSKA M. 2006b. Appendix 2. Flagellum-bearing Hydrobioids. 1. Emmericia (Gastropoda: Prosobranchia: Rissooidea): From morphology to molecules and back to morphology. Folia Malacol. 14: 152-161.

SZAROWSKA M., FALNIOWSKI A. 2011. An unusual, flagellumbearing hydrobiid snail (Gastropoda, Rissooidea, Hydrobiidae) from Greece, with descriptions of a new genus and a new species. J. Nat. Hist. 45: 2231-2246. doi: $10.1080 / 00222933.2011 .591067$

Szarowska M., FALniowski A., Riedel F., Wilke T. 2005. Phylogenetic relationships of the subfamily Pyrgulinae (Gastropoda: Caenogastropoda: Hydrobiidae) with emphasis on the genus Dianella Gude, 1913. Zootaxa 891: $1-32$.

SZAROwSKa M., GrZMil P., FALNiOWSKi A., SirbU I. 2007. Grossuana codreanui (Grossu, 1946) and the phylogenetic relationships of the East Balkan genus Grossuana (Radoman, 1973) (Gastropoda: Rissooidea). Hydrobiologia 579: 379-391. doi: 10.1007/s10750-006-0530-4

THIELE J. 1929-1935. Handbuch der systematischen Weichtierkunde. Gustav Fischer Verlag, Jena.
Thompson J. D., Gibson T. J., Plewniak F., JeAnMougin F., HigGins D. G. 1997. The ClustalX windows interface: flexible strategies for multiple sequence alignment aided by quality analysis tools. Nucl. Acids Res. 24: 4876-4882. doi: $10.1093 /$ nar/25.24.4876

Wilcox T. P., ZWickl D. J., HeATH T. A., Hillis D. M. 2003. Phylogenetic relationships of the dwarf boas and a comparison of Bayesian and bootstrap measures of phylogenetic support. Mol. Phyl. Evol. 25: 361-371. doi: 10.1016/ S1055-7903(02)00244-0

Wilke T., DAVIS G. M. 2000. Infraspecific mitochondrial sequence diversity in Hydrobia ulvae and Hydrobia ventrosa (Hydrobiidae: Rissoacea: Gastropoda): Do their different life histories affect biogeographic patterns and gene flow? Biol. J. Linn. Soc. 70: 89-105. doi: 10.1111/ j.1095-8312.2000.tb00202.x

Wilke T., DAVIS G. M., FAlNiOWSKI A., GiUSTI F., BODON M., SZAROWSKA M. 2001. Molecular systematics of Hydrobiidae (Gastropoda: Rissooidea): testing monophyly and phylogenetic relationships. Proc. Acad. Nat. Sci. Philadelphia 151: 1-21. doi: 10.1635/ 0097-3157(2001)151 [0001:MSOHMG]2.0.CO;2

Wilke T., Davis G. M., Chen C. E., Zhou X.-N., ZenG X. P., Zhang Y., SPOlskY C. M. 2000a. Oncomelania hupensis (Gastropoda: Rissooidea) in eastern China: molecular phylogeny, population structure, and ecology. Acta Tropica 77: 215-227. doi: 10.1016/ S0001-706X(00)00143-1

Wilke T., DAVIS G. M., GONG X., LIU H. X. 2000b. Erhaia (Gastropoda: Rissooidea): phylogenetic relationships and the question of Paragonimus coevolution in Asia. Amer. J. Tropic. Medic. Hyg. 62: 453-459.

Wilke T., FALniowski A. 2001. The genus Adriohydrobia (Hydrobiidae: Gastropoda): polytypic species or polymorphic populations? J. Zool. Syst. Evol. Res. 39: 227-234. doi: 10.1046/j.1439-0469.2001.00171.x

Wilke T., HAASE M., Hershler R., LiU H.-P., Misof B., PONDER W. 2013. Pushing short DNA fragments to the limit: Phylogenetic relationships of 'hydrobioid' gastropods (Caenogastropoda: Rissooidea). Mol. Phyl. Evol. 66: 715-736. doi: 10.1016/j.ympev.2012.10.025

XIA X. 2000. Data analysis in molecular biology and evolution. Kluwer Academic Publishers, Boston, Dordrecht \& London.

Xia X., Xie Z., Salemi M., Chen L., Wang Y. 2003. An index of substitution saturation and its application. Mol. Phyl. Evol. 26: 1-7. doi: 10.1016/S1055-7903(02)00326-3

Received: November 14th, 2012

Revised: February 26th, 2013

Accepted: February 28th, 2013 